\title{
Mulheres nas arquibancadas: as performances e enfrentamentos das torcedoras cariocas
}

\author{
Nathália Fernandes Pessanha* \\ ORCID ID: 0000-0001-8792-0405 \\ Universidade Federal Fluminense, Departamento de História, Niterói, Brasil
}

Resumo: $\mathrm{O}$ presente artigo tem por objetivo trazer à tona discussōes a respeito da vivência e dos enfrentamentos pelos quais passam as torcedoras, denominadas aqui como comuns, nas arquibancadas do Rio de Janeiro. A partir da realizaçâo de entrevistas com quatro torcedoras, busca-se tratar de temáticas que são recorrentes nas experiências de mulheres que frequentam estádios, percebendo esse espaço como um ambiente capaz de criar e reiterar lógicas que ampliam o senso comum de que o futebol é masculino.

Palavras-chave: Gênero. Torcedoras. Arquibancadas.

\section{Womens in the bleachers: the performances and confrontations of cariocas football supporters}

Abstract: This article aims to bring up discussions about the experience and the clashes that football supporters, named here as ordinary, go through in the bleachers of Rio de Janeiro. Based on the interview with four supporters, the aim is to deal with themes that are recurrent in the experiences of women who attend stadiums, perceiving this space as an environment capable of creating and reiterating logics that broaden the common sense that football is male.

Keywords: Gender. Supporters. Bleachers.

Doutoranda em História pelo Programa de Pós-Graduação em História da Universidade Federal Fluminense (PPGH-UFF), mestre em História pela mesma instituição. E-mail: nathaliafp@id.uff.br. 


\section{Pontapé inicial}

"Torcer é entrar em uma ordem discursiva, e torcer em um estádio de futebol exige do sujeito que quiser essa identificação atitudes específicas" (Bandeira, 2019, p. 91).

Gustavo Bandeira, em sua tese de doutorado defende que um currículo de masculinidades perpassa os estádios de futebol, currículo esse que acabou sendo questionado ou modificado nas novas arenas esportivas que nasceram em concordância com todo o processo de modernização do esporte. Isso implica modos de torcer que são necessários para que o indivíduo seja considerado partícipe das manifestaçóes torcedoras nos estádios. Por muito tempo, e ainda hoje, essas manifestações incluíam e incluem casos de racismo, machismo e homofobia que, gradativamente, vêm sendo questionadas pelas autoridades esportivas e pelos próprios torcedores e torcedoras.

Dessa maneira, ser torcedor ou torcedora de futebol exige certa pedagogia, certo modus operandi dentro e fora dos estádios de futebol. Ser uma mulher torcedora exige ainda mais desse entendimento e comportamento torcedor, já que implica estar inserida em uma lógica que é machista e a segrega dentro do próprio espaço do torcer.

É intenção do artigo trazer para o debate como é ser torcedora comum $^{1}-$ ou seja, aquela que não pertence a nenhuma torcida organizada stricto senso - e estar nas arquibancadas no Rio de Janeiro (RJ) hoje. ${ }^{2}$ Nesse sentido, algumas indagaçóes norteiam a reflexáo aqui desenvolvida sobre ser torcedora nesse universo que ainda é considerado como masculino. Como, por exemplo, quais as pedagogias que ainda permanecem e são perpassadas no estádio? Quais as que estão sendo alteradas pelas próprias torcedoras, através de movimentos de mulheres e setores femininos? Quais as dificuldades que enfrentam, quais as questóes que se apresentam para seu cotidiano torcedor?

\section{Primeiro tempo - Identidades e pertencimentos torcedores}

Segundo Bernardo Buarque de Hollanda (2009), a prática do torcer pode ser metaforicamente associada à assistência do teatro grego. $\mathrm{O}$ público das peças de

1 O termo torcedor comum já foi utilizado em outros trabalhos sobre torcidas, contudo é um termo que não qualifica adequadamente aquele torcedor ao qual estamos nos referindo. Chamar um torcedor de comum, não implica que outra categoria torcedora seja 'especial'. É apenas uma maneira de diferenciar o torcedor ou torcedora não organizado(a) daqueles(as) que pertencem a alguma forma de associativismo. Não é propósito desse trabalho pensar novas nomenclaturas ou categorias que melhor expressem a qualificação do torcedor ou torcedora em questão. Portanto, embora ciente da problemática em torno termo, para fins deste artigo ele será utilizado, apenas com o intuito de diferenciar o(a) torcedor(a) que vai ao estádio regularmente, porém não faz parte de nenhum agrupamento.

2 A escolha das entrevistadas seguiu alguns critérios. Primeiramente, a assiduidade nos estádios e a não participação em algum agrupamento associado ou organizado. Depois, a faixa etária, compreendida 
teatro encontrava-se em estado de catarse, encarnando meros assistentes passivos do espetáculo, associando essa recepção passiva à paixão de maneira quase patológica. Por muito tempo, e de certa forma ainda hoje, o futebol foi pensado dessa forma, sendo entendido como o "ópio do povo", responsável pela catarse daquele que assiste ao espetáculo, tornando a assistência dependente daqueles que jogam e capazes de, por eles, cometerem atos passionais.

De acordo com Luiz Henrique de Toledo (2010), para além da dimensão catártica do torcer, outras variáveis entram em jogo quando se trata da assistência por um time de futebol e do pertencimento clubístico. $\mathrm{O}$ autor aponta que as experiências da arquibancada não se limitam nem se encerram em um estádio de futebol. $\mathrm{O}$ cotidiano está repleto da vontade de torcer.

Nesse sentido, a identidade é concebida a partir da experiência compartilhada, surgindo da relação entre subjetividades distintas. Dessa tensão, nascem as formas de relação identitária. Assim, também é possível argumentar que a identidade torcedora estaria menos associada aos marcadores sociais de classe, etnia e ideologia, e mais associados aos círculos íntimos aos quais pertencemos como o círculo familiar, os amigos do bairro, da escola, etc. Como demonstram as entrevistadas que, quando perguntadas sobre sua inserção inicial nas torcidas, responderam sobre a influência familiar:

Então, a minha inserção no universo do futebol foi definitivamente minha, eu não cresci numa família que é apaixonada por futebol, hoje em dia até que meus pais gostam também, minha mãe gosta bastante principalmente, mas a inserção foi por mim, quando eu tinha 11 anos eu comecei a me interessar muito por futebol. Eu já torcia pro Botafogo por causa da família, mas a gente era botafoguense só por falar mesmo, e eu comecei a me interessar muito por futebol e a encher o saco 'mãe, me leva no maracaná pela primeira vez?', isso em 2007, antes de eu fazer 12 anos, eu tinha 11 ainda, no início de 2007. [...] Interessante que tinha muito mais mulheres que homens nesse momento e minha vida no futebol foi marcada por isso, por muitas mulheres ao meu redor, ainda bem, porque quem me influenciou na minha escolha pelo meu time foi minha máe e o meu tio, irmáo dela, que náo mora no Rio de Janeiro, mora em Brasília, mas é botafoguense. [...] Eu e minha mãe somos as mais apaixonadas aqui de casa, por futebol. (Ana Luiza Gomes, 2019).

É interessante destacar que, apesar da torcedora ter iniciado sua fala afirmando que sua inserção nas torcidas se deu de maneira autônoma, ela acaba por recorrer à lembrança da presença materna acompanhando-a nos jogos e sendo o que mais se

entre 20 e 29 anos, entendida como pertencente à juventude. Além disso, todas as entrevistadas pertenciam à classe média/média-baixa, e estavam cursando ou já haviam concluído o ensino superior em universidades públicas. As entrevistas foram realizadas a partir de questionário próprio que possibilitou a reprodução das mesmas perguntas para todas as entrevistadas. 
aproxima de uma influência para se apaixonar pelo futebol e seu time. Da mesma forma, Flávia também aponta a presença materna como fundamental para sua inserção no universo futebolístico, bem como sua companhia nos jogos.

$\mathrm{Na}$ minha casa é muito forte a presença do meu pai e da minha mãe, assim, os dois são muito fanáticos e eu comecei a ir a estádio mesmo com uns 12 anos, que até então meus pais tinham um pouco de medo de me levar, eles gostavam muito, a gente assistia muito futebol em casa, mas para eles me levarem a estádio demorou um pouco. [...] Hoje em dia quem vai muito comigo é minha máe, meu pai não vai mais. Quem vai muito comigo é minha mãe. (Flávia Muniz, 2019).

A menção à importância da presença materna para as duas torcedoras entrevistadas demonstra que a presença feminina e o interesse das mulheres pelo futebol já estavam presentes em geraçóes anteriores, ratificando que o interesse feminino por futebol não é recente, ainda que as torcedoras estivessem em menor número.

Poliana também recorre à presença familiar para explicar sua iniciação como torcedora de futebol:

Inicialmente, minha família toda era flamenguista e queria me empurrar para torcer para o Flamengo. Até que meu pai me levou ao Maracanã, ainda o Maracanã antigo, para ver um jogo do Fluminense, e ali eu me apaixonei quando eu tive aquele contato de estar no estádio, com a torcida e ver o Fluminense ganhando. Eu tinha o quê? De uns nove para dez anos e eu me apaixonei por futebol e comecei a torcer para o Fluminense. (Poliana Chaves, 2019).

Já Daniela, embora também mencione a importância familiar em sua inserção no mundo do futebol, associa isso ao mundo do trabalho, uma vez que seu pai procurou ser atleta profissional durante a juventude. Para ela, ir ao trabalho do pai e ao divertimento nos estádios eram coisas semelhantes:

$\mathrm{Na}$ verdade, o futebol sempre foi presente na vida porque o meu pai jogava bola, jogava pelo Campo Grande, ele tentou ser profissional em algum momento da vida dele, só que aqueles caminhos que a vida vai te levando para outros lados não deu certo. Entáo, eu passava meu domingo na beira de campo vendo o futebol de várzea que, aliás, é um dos meus passatempos preferidos até hoje. (Daniela Araújo, 2019).

Mas a identidade torcedora traz consigo ainda outro aspecto: ninguém torce sozinho. E ninguém torce por um time sem torcer contra outro. Essa outra face da identidade, que ao mesmo tempo produz diferenças, tem a ver também com seu próprio ritmo de construção. É a partir do outro que defino quem sou. Seja através das rivalidades construídas ou das amizades conquistadas. Essa construção do outro nas arquibancadas pode assumir muitas vezes papéis de hostilidade com a diferença. 
A construçáo da masculinidade também perpassa o estádio de futebol e é importante pontuar aqui que a construção do outro no estádio de futebol, na maior parte das vezes, passa pela diferenciaçáo da masculinidade e do gênero. O pertencimento ou o gosto das mulheres pelo esporte é questionado devido, sobretudo, à construçáo social feita sobre a mulher, como dona do lar e do espaço doméstico, náo do campo de futebol, ou das arquibancadas, reafirmando as diferenciaçóes entre aqueles que devem participar do espaço público e do privado.

Ser torcedora, portanto, passa por uma série de determinaçóes e pertencimentos que mulheres são submetidas para serem inseridas nesse universo para o qual, muitas vezes, como apontaram as entrevistadas, o incentivo vem de casa.

\section{Intervalo - As diferenciações de gênero e as pedagogias da arquibancada ${ }^{3}$}

Mas afinal, o que é essa determinação de gênero nas arquibancadas? $\mathrm{O}$ que diferencia o comportamento de homens e mulheres, e delimita aquele espaço como um espaço masculino? A frase de Simone de Beauvoir que diz que "ninguém nasce mulher, torna-se mulher" (Beauvoir, 1970) é interessante para iniciar uma tentativa de resposta a essas questóes. O que a filósofa afirma com essa frase é que ser mulher e, por consequência, ser homem, é uma construçáo social.

Da mesma maneira, é possível pensar que a masculinidade também é construída através de meios sociais e de modus operandi que são ensinados e, de certa forma, exigidos do gênero masculino. As arquibancadas, tidas por muito tempo como lugar de homem, acabam por traduzir, ou por esperar que se produza, uma performance de masculinidade definida, reproduzindo um padrão entendido como masculino e heterossexual. De acordo com João Moura, a própria arquitetura dos estádios de futebol, contribuem com a ideia de serem os mesmos locais de pertencimento masculino. Como analisa o autor, "o espaço circular (via de regra) dos estádios de futebol remete às arquiteturas do grande Coliseu romano, no qual, curiosamente ou não, eram encenados espetáculos de luta que determinavam a virilidade masculina" (Moura, 2019, p. 49).

Os estádios de futebol, portanto, são locais onde essa masculinidade se produz e reproduz. É comum, portanto, que cada agrupamento específico se localize em um lugar determinado do estádio, pois aquele local demarca um pertencimento para aquela torcida ou agrupamento, ou mesmo para torcedores individuais. Quando questionadas a respeito do local de arquibancada que costumavam frequentar, as torcedoras apontavam locais com os quais se identificavam, como foi o caso da Flávia, que disse: "eu sempre fico no setor Norte, e eu tenho ultimamente ficado na pilastra 41 ali do

Aqui utilizo o termo como apresentado por Gustavo Bandeira (2019), como será melhor explicado ao longo do texto. 
setor Norte do Maracanā" (Flávia Muniz, 2019). Em outro momento da entrevista, ela explicou que a escolha por essa localizaçáo se deve ao fato de as meninas do grupo ao qual ela faz parte marcarem de se encontrar ali. Ou, ainda, a Daniela, que afirmou: "eu fico geralmente entre a Mancha e a TOV que é mais pra lateral do campo" (Daniela Araújo, 2019), explicando também que essa localização se deve à sua identificação com as duas torcidas organizadas ou com alguns membros destas. Ou seja, a arquibancada não é um espaço neutro, são desenhados nela locais de pertencimentos e os torcedores, mesmo os chamados comuns, se identificam com determinada localização.

Não obstante, além de determinar locais de pertencimentos, os estádios e as arquibancadas, especificamente, exercem certo ensinamento. Como já mencionado, permitem produzir e reproduzir determinadas normas e formas de conduta consideradas como padrão. Em função disso, Bandeira afirma que os estádios papel pedagógico. Para ele,

Os estádios de futebol podem ser pensados como um contexto cultural específico, que ensina comportamentos, valores, formas 'corretas' ou 'adequadas' de práticas diversas por meio de seu desenho arquitetônico, cânticos repetidos e performances explicitadas. Os estádios se constituem como um artefato cultural, eles são produzidos, são feitos e são portadores de pedagogias. Os estádios são coisas concretas, não apenas porque são feitos de concreto, mas porque se constituem como artefatos portadores de pedagogias de gênero e de sexualidade, dentre outras pedagogias culturais. É necessário passar por diferentes processos de aprendizagem para que os sujeitos possam ser introduzidos nesse contexto cultural. Estar em um estádio de futebol significa passar por diferentes pedagogias. É necessário aprender quando gritar, quando calar, o que gritar, o que calar, o que e como sentir. (Bandeira, 2019, p. 116).

Dentro dessa pedagogia da arquibancada, o padrão heteronormativo masculino é exaltado, fazendo com que até alguns agrupamentos progressistas tentem se enquadrar dentro de alguma espécie de padrão.

Essa masculinidade esperada nas arquibancadas acaba reiterando a velha lógica de que a mulher não pertence àquele ambiente, bem como promovendo falas homofóbicas e misóginas, no intuito de afirmar a sua identidade, ou de sua torcida como superior ou melhor que a adversária. Como argumenta Bandeira, em estudo sobre as torcidas de Grêmio e Internacional, no Rio Grande do Sul, mas que podem, de certa maneira, serem transpostas à realidade carioca e nacional, os gritos, cantos e falas machistas ou homofóbicas servem como diferenciador do eu com o outro. Segundo Bandeira:

Parece que, dentro das representaçóes heteronormativas da nossa masculinidade colorada ou gremista, as identidades homossexuais aparecem sempre desvalorizadas. É esta lógica heteronormativa, onipresente e recorrente, que impede - nos estádios, espaço de marcação da masculinidade - a positivação do termo. Nos estádios de 
futebol, os gritos homofóbicos aparecem para hierarquizar a nossa torcida em relação à torcida deles. (Bandeira, 2019, p. 349).

Nesse sentido, é interessante pensar de que maneira essa heteronomatividade, ou a masculinidade exacerbada dos estádios de futebol afetam diretamente a vivência e a presença feminina nas arquibancadas, determinando o que enfrentam por se dizerem torcedoras de futebol e por frequentarem um ambiente considerado eminentemente masculino.

\section{Segundo tempo - A vez das torcedoras comuns}

Muitas das pesquisas sobre torcidas e o torcer têm se debruçado, primordialmente, sobre os torcedores (homens) organizados. Contudo, como já argumentava Bandeira, os torcedores considerados comuns, que frequentam os estádios com regularidade, mas não são associados a nenhuma torcida específica, também personificam diversas características do torcer e são educados a partir da pedagogia dos estádios e das arquibancadas, para que possam efetivamente participar do pertencimento àquele ambiente.

Entre as torcedoras, essa disputa não é menos verdadeira. Ainda é muito corriqueiro se ouvir dizer que as mulheres entendem menos que os homens de futebol porque não o praticam, muito embora essa afirmação venha sendo questionada e criticada por fẫs do esporte e pesquisadores, como é o caso do sociólogo Arlei Damo (1998). Damo afirma que o entendimento sobre uma partida de futebol é resultado da comunicaçáo estabelecida entre o ato e a reação que este suscita. Sem menosprezar a relevância da experiência, o autor argumenta que, percebendo o jogo como uma linguagem e considerando os jogadores como emissores e os torcedores como receptores, cada lance corresponderia a um código que precisaria ser decifrado por quem está na arquibancada.

Sendo assim, tem-se que, por um lado, determinado lance pode ser compreendido mesmo por quem não está diretamente envolvido nele ou ainda, por quem jamais participou de um evento similar. Basta, para tanto, que ao evento seja atribuído um sentido e isto está ao alcance de qualquer indivíduo independente da questão de gênero. (Damo, 1998, p. 63).

Nesse sentido, é importante observar a relevância do papel da memória coletiva na formação e ratificação desse pensamento estereotipado. A prática do futebol por mulheres foi proibida por decreto no Brasil por quase quarenta anos (1941-1979), e essa proibição deixou vestígios na vida e na memória das mulheres que gostam de 
futebol e da sociedade de modo geral.

Pode-se argumentar ainda que o preconceito de gênero e a crença da inferioridade feminina no conhecimento e na prática do futebol se iniciam dentro dos próprios clubes. Poucas são as mulheres que ocupam papéis de liderança dentro das diretorias dos clubes brasileiros e cariocas, e aquelas que lá chegam, sofrem diversos preconceitos e pré-julgamentos de suas atitudes pela questáo do gênero. Segundo Marcelo Pizarro de Noronha (2012), foi somente na década de 1990 que uma mulher conseguiu alcançar um cargo como dirigente de futebol. Ela foi Marlene Matheus, que dirigiu o Sport Club Corinthians Paulista entre 1991 e 1993, esposa do ex-dirigente do clube, Vicente Matheus. O que levou a ser questionada quanto às suas habilidades como dirigente, argumentando-se que quem de fato dirigia o time 'nos bastidores' era seu marido.

Essa escassez de mulheres em papeis de liderança dentro dos clubes e times dialoga fortemente com a questão da representação no esporte, táo pleiteada não somente pelas mulheres, mas por todas as minorias. ${ }^{4}$ A diferença de representaçóes, de busca por espaços e cantos de torcida que pertençam ao seu universo, é um tema constante entre aquelas que gostam e participam do futebol.

Esse argumento é importante se considerarmos artigo de Casagrande (2018) sobre a presença de mulheres em capas de jornal na Copa do Mundo de Futebol, em 2014. As imagens femininas estavam sempre associadas à derrota e ao descontrole emocional, ao choro, ao desespero. Outro aspecto interessante a ser mencionado é que, em pesquisa realizada por mim em diversos números da revista Lance. ${ }^{5}$ do ano de 2006, ano da Copa do Mundo da Alemanha, e também ano de fundação de uma torcida organizada feminina no Rio de Janeiro, a Flu Mulher, pertencente ao Fluminense Football Club, a única reportagem encontrada com menção a torcedoras femininas em diversos números, dizia respeito a beleza da torcedora que se preparava para assistir aos jogos da Copa, em editorial intitulado "Beldades da Copa", com a manchete anunciando: "Essa não foi para outra seleção... sorte a nossa" (Beldades..., 2006). Quando questionadas sobre o que elas pensavam sobre o que é, efetivamente para elas entendido como representação feminina no futebol, as entrevistadas responderam:

[...] só se tem representatividade com determinada coisa ocupando lugar de destaque ou de protagonismo, entáo representatividade feminina no futebol é a valorização do futebol feminino, é a valorização das mulheres que jogam futebol,

4 O termo representação é aqui utilizado de acordo com o argumento de Sandra Makowiecky: "Mas de todos esses usos da palavra, pode-se reter um ponto em comum: a representação é um processo pelo qual institui-se um representante que, em certo contexto limitado, tomará o lugar de quem representa" (Makowiecky, 2003, p. 4).

5 A pesquisa foi realizada com as revistas pertencentes ao acervo do Centro de Referência do Futebol Brasileiro (CRFB), do Museu do Futebol, entre 26 e 28 de setembro de 2018. 
porque elas também são protagonistas nesse esporte [...]. E é isso, representatividade feminina passa por isso. Eu acho que tem outras questóes que aí, infelizmente, eu acho muito mais difíceis, por exemplo, técnicas mulheres, eu sinceramente nem tenho esperança de que isso aconteça. Mas a questão do futebol feminino e árbitra mulher já são questóes muito importantes e que precisam ser vistas e faladas. (Ana Luiza Gomes, 2019).

Dar mais espaço ao futebol feminino. Porque agora está começando a todo clube ser obrigado a ter um time feminino de futebol, só que eu acho que a gente precisava de mais visibilidade também. O que adianta a gente ter um campeonato brasileiro se a gente nem sabe dos jogos direito? Não tem transmissão. Então, eu acho que tinha que ter mais espaço na arquibancada também e no próprio futebol, no próprio jogo. (Poliana Chaves, 2019).

A Copa do Mundo Feminina, realizada na França, em 2019, teve pela primeira vez a cobertura da Rede Globo de televisão para os jogos da seleção brasileira feminina, em concomitância com a Copa América masculina, realizada no Brasil. A despeito da menor divulgação da seleção feminina em comparação com a masculina dada pela própria emissora, é possível argumentar que, de certa forma, o desejo de representaçáo feminina no futebol expressado por ambas as entrevistadas vem, paulatinamente, sendo alcançado.

Por outro lado, Flávia e Daniela já apontaram caminhos que, embora mencionassem o futebol feminino, iam mais longe. Flávia recorreu ao argumento da presença das mulheres em papéis de liderança dentro dos próprios clubes, para ela:

Acima de tudo eu acho que participação ativa da mulher dentro da diretoria. Claro que a gente tem o futebol feminino, a gente tem mulher na arquibancada, isso é muito importante, mas eu acho que não vai existir uma valorização do futebol feminino enquanto não tiver uma voz ativa feminina dentro de conselhos, de diretoria, de vice-presidência, enfim [...]. O Flamengo, visando isso, resolveu fazer um programa chamado Fla-Mulher e aí um belo dia eu fui a Gávea pra conhecer o Fla-Mulher e as medidas que elas têm, e são algumas senhorinhas que fazem passeios, vão pra Aparecida e tudo mais, e fazem camisa 'Fla-Mulher' e fazem uma tarde de chás. (Flavia Muniz, 2019).

Daniela também destaca a participação de mulheres nas mais diversas áreas do esporte:

Primeiro, acredito que hoje é o apoio e o fortalecimento do futebol feminino, isso seria realmente uma representatividade. Além disso, ter técnicas, árbitras, bandeiras, dirigentes, jornalistas, chefes de torcida, ter mulheres em cargos, vamos dizer assim, dentro da hierarquia social do futebol em posiçóes mais elevadas, em 
posiçôes de destaque. (Daniela Araújo, 2019).

Atualmente, também vêm ganhando espaço na mídia maior número de jornalistas esportivas. Da mesma maneira, narradoras e trabalhadoras de outras funçóes como árbitras e bandeirinhas têm recebido mais apoio, sobretudo da mídia. Quando questionadas se essa maior presença feminina nos bastidores do esporte tinha alguma influência em um maior interesse das mulheres por futebol e sua participaçáo nas torcidas, responderam:

Eu acho que se pode fazer essa associação, sim, entre outras coisas, mas eu acho que a maior participação de mulheres em programas esportivos, que é o que está na mídia, é o que as pessoas estão vendo. As pessoas tão vendo que as mulheres estáo participando mais do esporte de um modo geral, né. Então, eu acho que se pode fazer essa associação, sim, e eu percebi assim, eu frequento estádio há 12 anos, vai fazer 12 anos, desde 2007, e eu percebo um crescimento no interesse e na participação das mulheres nos estádios. (Ana Luiza Gomes, 2019).

Nunca parei para observar esse lado do jornalismo, com mulheres na arquibancada, mas eu percebo hoje em dia muito mais mulheres assim, à frente ali, torcendo do que quando eu comecei a frequentar estádio há 10 anos. (Poliana Chaves, 2019).

É importante mencionar que a relação entre o maior interesse das mulheres no esporte e a maior presença de mulheres nos bastidores náo pode ser afirmada para fins deste trabalho, essa pesquisa não foi por mim elaborada, é apenas uma associação teórica. Nesse sentido, Flávia e Daniela apontaram um caminho diferente. Elas entendem que a relaçáo entre as mulheres na mídia e a maior presença de mulheres na arquibancada podem ser percebidos como movimentos simultâneos, como destaca Flávia, ou ainda que o processo é, ao contrário, a busca por espaço das mulheres é o que garante as mulheres na mídia, como aponta Daniela.

Não sei até que ponto tem uma relação diretamente... eu acho que tudo está conectado na verdade, porque hoje mais do que antigamente a gente tem um apelo maior, que lugar de mulher é onde ela quiser. Então, eu acho que agora, hoje em dia, a gente está caminhando para um lugar mais acessível para as mulheres, aos poucos, claro, mas eu acho que a abertura do clube para isso, tanto nas campanhas que eles vinham fazendo quanto as pessoas mesmo criam consciência de que lugar de mulher é onde ela quiser, então já vi várias torcedoras no estádio com faixas com essa frase [...]. Então, eu acho que com a ascensão dos movimentos feministas e com a mulher se entendendo como indivíduo participativo na sociedade, eu acho que isso tem influenciado, tanto na participação das mulheres na televisão, no futebol como árbitras e tudo mais, tanto nos estádios. (Flávia Muniz, 2019). 
$\mathrm{Na}$ verdade, eu acho que é o contrário, as mulheres sempre estiveram presentes e sempre foram interessadas por futebol, tem uma aura que diz que a mulher não gosta de futebol, mulher não entende de futebol, mulher não vai ao estádio, futebol náo é para a mulher. [...] Eu acho que assim, a partir do momento que as mulheres sempre tiveram interesse por futebol e que elas começaram a poder estudar, se inserir no mercado de trabalho, e ai entáo conseguir ter uma abertura na mídia pra ser repórter de campo, ou começaram a ter uma abertura na mídia esportiva, essa abertura ainda é muito relativa, porque é uma abertura que é obedecendo a um padrão, que eu até brinco, que é um padrão Fernanda Gentil, que é aquela mulher loira, magra, alta que é divertida, são poucas mulheres negras, por exemplo, que se têm, no jornalismo em geral e, especificamente, no jornalismo esportivo, é uma, uma assim [...] Não acho que por ter uma repórter na beira de campo a mulher se interesse por futebol, eu acredito que a mulher se interessa por futebol e aí ela tem o interesse pela profissão do jornalismo. (Daniela Araújo, 2019).

Essa fala da Daniela é ainda interessante por outros aspectos. Primeiro, porque a entrevistada, enquanto formada em jornalismo e pesquisadora do tema das torcidas, possui uma visão mais ampla da presença das mulheres no espaço profissional, no qual ela, grosso modo, se enquadra. Espaço que é diferente do daquelas torcedoras que veem a atuação dessas mulheres apenas das arquibancadas ou da televisão. Além disso, Daniela destaca a importância da mulher negra. Essa percepção perpassa também pelo local de pertencimento e fala da entrevistada, e de suas lutas próprias. ${ }^{6}$ Isso nos mostra que a luta das mulheres negras é muito mais ampla, que perpassa não só as questões de gênero, mas também de raça/etnia. E que a luta por representaçáo feminina no esporte vai muito além de apenas conseguir que mulheres que respondam ao 'padrão' (branco), sejam representadas e tenham suas demandas ouvidas.

\section{Prorrogação - Machismo, homofobia e heteronormatividade}

Quando falamos em torcida mista, aquela que agrega homens e mulheres, falamos de torcidas que, embora contemplem todo tipo de torcedor, carregam valores e estereótipos característicos da masculinidade dominante, e, segundo Juan Branz, "esa masculinidad dominante se caracteriza por la centralidad de la heterosexualidad como mandato, conjuntamente con una activa sexualidad que se corresponda con el ejercicio

O termo lugar de fala é aqui utilizado não com o intuito de exclusão ou segregação de um grupo, mas no sentido de privilegiar e reconhecer os diferentes locais e pertencimentos existentes. Segundo Djamila Ribeiro: "Entendemos que todas as pessoas possuem lugar de fala, pois estamos falando de localização 
viril de ese modelo masculino" (Branz, 2017, p. 6). ${ }^{7}$ A torcida é mista, seus valores não. Nesse sentido, muitos dos aspectos atribuídos à torcida não representam e não fazem jus aos desejos e pertencimentos femininos.

Quando questionadas sobre qual tipo de atitude de suas torcidas ou de outras as incomodavam nos estádios, Ana Luiza e Poliana traçaram respostas no sentido de criticar ou questionar esse comportamento:

Nossa, essa pergunta é perfeita, porque a gente está em 2019 e muitas atitudes de torcidas me incomodam, as torcidas precisam evoluir. Eu sou muito irritada com o discurso de que 'ah, o futebol moderno é muito chato, o futebol moderno estragou a torcida', assim, eu tenho muitas críticas ao futebol moderno, mas as minhas críticas são sobre elitização, a estádios que o acesso muitas vezes é negado a pessoas de baixa renda, os ingressos são caros, os programas de sócio torcedor não são atrativos, pra você consumir dentro do estádio é um absurdo, os estádios não tem mais setor pra que você fique em pé, entáo, essa crítica ao futebol moderno eu tenho, acho que o futebol na sua essência ele é popular, ele é do povo e ele não pode ser elitizado, mas falar que o futebol moderno está estragando o futebol porque não se pode mais xingar o outro de veado, isso é um absurdo. As torcidas em geral são muito homofóbicas, muito homofóbicas [...]. Enfim, o que mais me incomoda de modo geral em torcida é isso. A homofobia é muito presente nos estádios, e isso é terrível. (Ana Luiza, 2019).

Tanto do Fluminense como qualquer outra torcida é muito homofóbica. Eu entendo que tenha a rivalidade, críticas ali. Eu acho que a gente pode reformular essa forma de rivalidade. Manter com respeito. (Poliana Chaves, 2019).

Atualmente, algumas entidades relacionadas ao esporte, como a Federaçăo Internacional de Futebol (FIFA), buscam resoluçóes que punam cantos e comportamentos homofóbicos nos estádios (Rizzo, 2014). Além da questâo da homofobia, diversas manifestaçóes de racismo também são recorrentes nas torcidas, como o caso do goleiro Aranha, do Santos, ofendido por torcedores do Grêmio, em 2014; do jogador Tinga, do Internacional, que ouviu ofensas racistas da torcida do Juventude; ou ainda do árbitro Márcio Chagas, insultado pelo técnico do time Encantado, que hoje estáo sendo vigiados mais de perto e sendo punidos, como

social. E, a partir disso, é possível debater e refletir criticamente sobre os mais variados temas presentes na sociedade. O fundamental é que indivíduos pertencentes ao grupo social privilegiado em termos de lócus social, consigam enxergar as hierarquias produzidas a partir desse lugar e como esse lugar impacta diretamente na constituição dos lugares de grupos subalternizados" (Ribeiro, 2017, p. 86).

7 Essa masculinidade dominante se caracteriza pela centralidade da heterossexualidade como regra, conjuntamente com uma sexualidade ativa que corresponda com o exercício viril desse modelo masculino (tradução livre da autora). 
informa o site Observatório da Discriminação Racial no Futebol (Casos..., 2018). Para Daniela, os cantos racistas foram também citados como cantos que a incomodavam.

Sáo os cantos racistas, sexistas e homofóbicos e as atitudes sexistas, racistas e homofóbicas. Principalmente se tratando daquilo que me dói, que é o racismo e o sexismo. Quando dói na carne a gente se mostra mais, vamos dizer assim. Então realmente, uma atitude sexista, quando fala 'ah, só vou comer, só vou isso, só vou aquilo', ou quando chama de 'macaco', ou quando chama de 'veado', essas coisas. Também não vou ser hipócrita de dizer que nunca chamei uma bandeirinha, uma gandula de gostosa, por exemplo. Também não vou dizer que nunca xinguei um juiz ou um jogador por uma fala homofóbica, não posso dizer isso, não vou ser hipócrita ao ponto de dizer que nunca fiz. Mas é algo que eu tento abolir das minhas atitudes porque realmente incomoda. Aquilo em coro realmente incomoda. (Daniela Araújo, 2019).

Flávia também mencionou em seu discurso o incômodo com cantos homofóbicos e racistas, contudo, sua menção mais específica se direcionou a atitudes e falas de sua torcida relacionadas à questão do machismo e a argumentos considerados como ofensivos.

Os cantos homofóbicos sempre me incomodam, que cantam para torcedor do Cruzeiro, do Fluminense, os jogadores do sul, do Inter, do Grêmio, enfim, sempre me incomodam. Os cantos racistas e preconceituosos, com preconceito de classe, que sempre tem para a torcida do Flamengo, de chamar de mulambo [...]. Enquanto mulher, me incomoda muito os xingamentos e até mesmo os elogios, por exemplo, já vi elogios a jogadores 'ah, você pode comer minha irmã'. Sabe, esse é o tipo de elogio do cara. 'ah, engravida minha irmã', coisas assim, né, entáo isso me incomoda. Não tem nenhum canto na torcida, mas é isso. [...] Os posicionamentos me incomodam mais do que os cantos em si, porque os cantos eu nunca ouvi muito direcionado a mulher, entấo os cantos homofóbicos são os que me incomodam mais. (Flávia Muniz, 2019).

A fala acima remonta ao argumento já utilizado de que os valores recorrentes nas torcidas, ainda que sejam tidas como mistas, são valores masculinos. As frases direcionadas às mulheres demonstram como ainda se considera que o futebol não pertence à mulher, e sentenças como "come minha irmâ" são tidas como normais, ou elogiosas. As torcedoras sofrem diversos tipos de machismos e discriminaçóes dentro e fora dos estádios quando assumem gostar de futebol e resolvem frequentar as partidas. Segundo elas:

Em termos de discriminação e preconceito com mulheres que gostam de futebol, eu sinto muito mais fora dos estádios do que dentro, porque eu acredito que a 
partir do momento que você se dispóe a ir no estádio, as pessoas já entendem que você gosta, e que você entende, que você tá por dentro, assim. Mas quando você se identifica como uma mulher que gosta de futebol, e fala de futebol e do seu time fora do estádio, a pessoa náo tem como saber se você realmente gosta e sempre rola aquela que a mulher tem que provar que realmente gosta de futebol, provar que ela entende, que isso e aquilo, que entende de regra, que conhece os jogadores do seu time, conhece a história do seu time, e com os homens isso não acontece, né? (Ana Luiza, 2019).

Eles falam que a gente não entende de futebol. Qualquer crítica que a gente faça a um jogador que para eles é bom, eles dizem: 'você não entende de futebol, você não entende de Fluminense'. E assim, isso ocorre não só dentro do estádio como nas redes sociais também. Se você for opinar, por você ser mulher, você já sofre uma repressão ali. 'Ah, mas você sabe do jogador que jogou no ano tal, o que ele fez, qual a história do Fluminense?' Eles acham que a história vai ser um jogador específico, em um ano específico, enfim. (Poliana Chaves, 2019).

Sim, eu sinto. Principalmente fora do estádio. Eu acredito que dentro do estádio eu sinto sim, eu sofro validação da minha fala, principalmente por pessoas que não me conhecem lá dentro, [...] mas fora do estádio é ainda pior. Porque são pessoas que não me conhecem, que não sabem meu histórico, que não me veem sempre, não reconhecem minha cara sempre nos estádios e começam a tentar invalidar a minha fala, e a questionar aquilo que eu vejo, que eu falo e muitas vezes o que eu pesquiso, a partir do momento que sou mulher, e muitas vezes eles acham que eu sou mais nova do que eu realmente sou. (Daniela Araújo, 2019).

Sim, já aconteceu de eu estar no meio da torcida organizada e aí eu ouvir, homens atrás de mim, falando que eu náo tinha que estar ali, que eu tinha que estar em casa, que eu não sabia torcer, enfim, já aconteceu sim [...]. Sempre vivencio fora, né, sempre naquela pergunta 'Ah, gosta de futebol? Então que que é um escanteio? Um impedimento?' Sempre tem, né, então tem que respirar fundo e responder, né, amigavelmente. Ou não. Mas outra coisa, quando querem me elogiar também. O elogio deles é 'Você parece até homem, gosta tanto de futebol, parece até homem'. Ok, isso é elogio, né, era para se rum elogio. Então assim, a gente vivencia bastante essas situaçóes assim. (Flavia Muniz, 2019).

É importante reiterar o argumento de que o cerceamento às opiniôes femininas gira em torno do suposto desconhecimento das mulheres sobre as regras do jogo e seus aspectos técnicos e táticos, argumento que dialoga com a memória corrente de que, por não ter praticado futebol, as mulheres não o conhecem. Além disso, segundo o depoimento da Flávia, as torcedoras são muitas vezes ainda hostilizadas nos estádios, com a afirmação de que aquele lugar náo pertence a elas. $\mathrm{O}$ que remete à velha lógica de que o espaço público é o espaço do masculino, enquanto o privado pertence ao 
feminino. ${ }^{8}$ As torcedoras precisam explicar as indagações feitas pelos demais torcedores para se sentirem e serem aceitas como pertencentes àquele universo, como participantes de determinada pedagogia que foi ensinada pela presença nos estádios. Sem mencionar os "elogios" recebidos ao associá-las ao masculino, no intuito de que isso signifique que elas participam do jogo simbólico do estádio e estáo inseridas na lógica torcedora. Esse mesmo tipo de comparação é feito com as jogadoras, quando uma delas, por se destacar no time pelo seu bom desempenho, muitas vezes, é comparada a um atleta do sexo masculino, ou afirma-se que ela "joga como homem". Além de toda discriminaçáo sofrida ao expor suas opinióes a respeito do jogo, dos jogadores ou do esporte de maneira geral, as mulheres torcedoras ainda têm que lidar com outra manifestaçáo do machismo que historicamente afeta as mesmas nas arquibancadas: o assédio. Atualmente, existem movimentos de mulheres específicos para lutar contra esse tipo de crime dentro das arquibancadas, como o Vascaínas contra o Assédio (Damaso; Grey, 2011). Contudo, o assédio ainda continua sendo um problema recorrente.

Nas arquibancadas é observado também a questáo da roupa utilizada. Mais uma vez, se percebe a reprodução nas arquibancadas da lógica machista e patriarcal de que as roupas utilizadas pelas mulheres determinam a maneira como as mesmas devem ser tratadas. $\mathrm{O}$ controle sobre o corpo feminino, sobre o que a mulher pode ou náo pode trajar para ser considerada como adequadamente vestida para determinado local, é reiterado nos estádios. Interessante perceber também que esse cerceamento sobre a roupa é reproduzido também por mulheres, que acabam ratificando essa mesma lógica machista e de restrição umas com as outras, como pode ser percebido através de episódio narrado pela Flávia.

Mas sobre as torcidas, no Flamengo, recentemente umas meninas se uniram para fazer um consulado, não lembro se era consulado ou uma embaixada, mas elas têm sede em Saquarema. Eu acho que é 'Consulado das minas', alguma coisa assim, que é só com mulheres. Consulados são tipo torcidas organizadas de uma certa região, né, que se juntam para assistir, para fazer caravana, para ir para jogo, para assistir jogo juntos, e aí elas fizeram, elas conseguiram, ir a Gávea, e que o presidente, o Landim, assinasse, reconhecendo como, não lembro se é consulado ou embaixada, mas posso ver para você depois. E aí eu descobri uma polemica que elas estavam envolvidas, que elas têm um grupo no WhatsApp, e começaram a falar mal de uma outra menina que estava indo pro Maracaná de top e que elas estavam falando que ela era piranha, que ela estava querendo aparecer, que ela não estava nem aí pro Flamengo, ela só queria ir e se mostrar, e tudo mais, e aí teve uma comoção no Twitter, teve uma briga enorme com a menina e tal, das meninas falando mal dela, entâo, era pra ser uma torcida que nos representaria, mas a mulher que quer ir de

8 Rachel Soihet, por exemplo, trabalha com a inserção das mulheres no espaço público através da luta pelo voto, observando a trajetória de Bertha Lutz (Soihet, 2000). 
top pro Maracanã não pode, porque ela tá sendo, né, tá sendo uma vadia, enfim, e aí eu decidi que eu náo ia segui-las porque, enfim, não tem nada a ver com o que eu acredito. (Flavia Muniz, 2019).

Em suma, o cerceamento sobre o corpo feminino está internalizado de tal forma que muitas mulheres acabam percebendo e reproduzindo como normal determinados tolhimentos. Espera-se sempre que a mulher se comporte de uma determinada maneira considerada como correta pelo "padráo" vigente, um padrão heteronormativo e masculino. As mulheres precisam se apresentar, performar uma apresentação que seja considerada sempre como digna para esse padrão. Espera-se que elas se apresentem sempre como belas, recatadas e do lar. ${ }^{9}$ Ou seja, a memória atua no sentido de ratificar e reproduzir estereótipos que se firmaram como padróes esperados para o corpo e atuaçáo feminina, influindo e sendo alimentado pela opiniáo pública que reitera cotidianamente os cerceamentos sobre o corpo feminino.

\section{Foi para os pênaltis - Algumas perspectivas}

Apesar de todas as dificuldades apresentadas pelas entrevistadas para ser mulher e torcedora em um estádio no Rio de Janeiro, enfrentando preconceitos, assédio, falta de representatividade e uma série de outras questóes que ainda precisam ser superadas. Ao serem questionadas sobre quais as atitudes o poder público, ou as próprias torcidas e os clubes deveriam tomar para que as arquibancadas fossem vistas como locais mais igualitários, levantaram uma série de questóes e modificaçóes que consideram necessárias para que isso aconteça. Ana Luiza destacou o papel fundamental da educação:

Eu acho que é fundamental, pauta de mudança principal e fundamental para uma mudança na arquibancada é uma mudança estrutural. Enquanto não se ensinar para as pessoas em todos os ambientes, principalmente nos ambientes educacionais, nos ambientes escolares, enquanto as crianças náo crescerem sabendo que estádio é lugar de mulher, e que mulher gosta de futebol e que isso é normal, enquanto não for uma mudança estrutural, botar a mudança só para dentro do estádio é ineficiente. (Ana Luiza Gomes, 2019).

Poliana recorreu à solicitação de uma mudança partindo de dentro do próprio clube e das próprias organizadas:

Eu acho que as organizadas permitirem mais que os núcleos femininos tenham

9 Frase utilizada em reportagem da revista Veja, ao se referir à ex Primeira-Dama, Marcela Temer, em 2016 (Linhares, 2016). 
mais espaço, sabe? Porque muitas vezes as mulheres querem ir para banda, por exemplo, e não pode, porque tem uma restrição. E eu acho que o próprio time podia chamar mais, fazer campanhas para atrair mais. Por que sempre criam a ideia de que mulher náo entende de futebol e que mulher está ali só acompanhando alguém, entendeu? (Poliana Chaves, 2019).

Flávia e Daniela, por outro lado, recorreram a questôes mais políticas e sociais para pleitear um local mais igualitário. Suas propostas iam desde a politização mais direta das torcidas, até pautas mais economicamente igualitárias, como o barateamento dos ingressos e acessibilidade para pessoas com deficiência.

Eu acho que a gente tem que parar com esse pensamento de que a gente náo mistura futebol com política, porque tudo na nossa vida é política [...] então a primeira mudança é a gente encarar o Flamengo e o futebol como um movimento do povo, um movimento de pessoas e a gente não pode pensar que a política náo está inserida ali porque está sim e quando a gente faz uma política de preços absurdamente caras, a gente está excluindo uma parte da sociedade [...]. Eu acho que a gente tem que ter campanhas contra a homofobia, por mais que tenha muito torcedor que diz 'ah, não posso mais falar nada, não posso mais torcer', cara, canta para o seu time aí, sabe, sem ofender o outro [...]. E eu acho que mais do que tudo os clubes devem incentivar as minorias a estar participando. As minorias de classe, de gênero, de orientação sexual. (Flávia Muniz, 2019).

Acredito que essa pergunta passa por diversos locais, posso interpretar de diversas formas, desde o barateamento do custo dos ingressos. Um policiamento eficaz. Açóes de combate ao racismo, de gênero, sexualidade. Acessibilidade real a pessoas com deficiência, que em muitos estádios, até mesmo nas arenas modernas, é complicado. [...] Num processo mais igualitário, acredito que o principal é a questão de barateamento dos ingressos. [...] Outra medida que eu considero importante são as açóes constantes e frequentes, usando, assim, entre aspas, um termo mais acadêmico, de docilizar aquela massa com relação os perfis contrastantes, ou seja, se você acha que o futebol é masculino, então você precisa que aquelas pessoas, aquelas virilidades, ela entenda que mulheres, gays, pessoas trans, brancos, negros, indígenas, crianças, adolescentes, é preciso que essa massa entenda, e realmente se veja como heterogênea. (Daniela Araújo, 2019).

É interessante notar que muitas das pautas levantadas por essas torcedoras comuns, quando questionadas a respeito das mudanças necessárias para um estádio e uma arquibancada mais igualitárias, são também pautas de torcedoras integrantes de torcidas organizadas e, em alguns casos, como na questão da igualdade social, também de alguns torcedores. Isso demonstra que ser uma mulher de arquibancada, organizada ou comum, engloba questóes mais amplas e lutas únicas, que perpassam as diferentes formas de torcer. 
Os movimentos de mulheres presentes hoje nas arquibancadas cariocas - e também de diversas partes do país, como o Vascaínas contra o Assédio, no Rio de Janeiro, ou o movimento Mulheres de Arquibancada, a nível nacional - bem como a criação de torcidas femininas, como a Flu Mulher, ou de alas femininas dentro das torcidas organizadas - demonstra não só que as formas de associação e organização nas torcidas de futebol hoje pode ser percebida de maneira muito ampla e englobante, mas também, e principalmente, que a luta por uma maior representatividade e espaço nas torcidas e no futebol de maneira geral pelas mulheres já começou e ganha cada vez mais espaço. São necessárias políticas públicas de apoio e incentivo à participação feminina, bem como campanhas dos clubes para incentivar a presença das mulheres nas arquibancadas cariocas para que essa participaçáo cresça e se multiplique cada vez mais. O futebol pertence também as mulheres, como já provam tais movimentos, hoje nacionalmente conhecidos e incentivados, que pleiteiam nada mais do que um espaço respeitado e digno para as mulheres no território do torcer.

\section{Referências}

BANDEIRA, Gustavo Andrada. Uma história do torcer no presente: elitizaçāo, racismo e heterossexismo no currículo de masculinidade dos torcedores de futebol. Curitiba: Appris, 2019.

BELDADES da Copa. Essa não foi para outra seleção... sorte a nossa. Lance!, Editorial, p. 10, 18 jun. 2006.

BRANZ, Juan Bautista. Masculinidades y ciências sociales: una relación (todavía) distante. Descentrada, La Plata, v. 1, n. 1, 2017.

CASAGRANDE, Magnos Cassiano. Imagens de torcedoras em capas de jornais: estudo sobre a Copa do Mundo de futebol de 2014. CONGRESSO BRASILEIRO DE CIÊNCIAS DA COMUNICAÇÃO, 41., 2018, Joinville. Anais... São Paulo: Intercom, 2018.

CASOS de racismo punidos pela justiça desportiva. Observatório da discriminaçāo racial no futebol, 9 maio 2018. Disponível em: https://observatorioracialfutebol.com.br/legislacao/casosde-racismo-punidos-pela-justica-desportiva/. Acesso em: 13 fev. 2020.

DAMASO, Jessyca; GREY, Gabriel. Vascaínas se unem na luta contra o assédio nos estádios de futebol. O Dia, 21 nov. 2011. Disponível em: https://odia.ig.com.br/esporte/ vasco/2018/11/5595035-vascainas-se-unem-na-luta-contra-o-assedio-nos-estadios-de-futebol. html. Acesso em: 1 jul. 2019.

DAMO, Arlei Sander. Para o que der e vier: o pertencimento clubístico no futebol brasileiro a partir do Grêmio Foot-Ball Porto Alegrense. Dissertação (Mestrado em Antropologia Social) UFRGS, Porto Alegre, RS, 1998.

HOLLANDA, Bernardo Buarque de. Futebol, arte e política: a catarse e seus efeitos na 
representação do torcedor. Organizações e Sociedade, Salvador, v. 16, n. 48, p. 123-140, 2009.

LINHARES, Juliana. Marcela Temer: bela, recatada e “do lar”. Veja, 18 abr. 2016. Disponível em: https://veja.abril.com.br/brasil/marcela-temer-bela-recatada-e-do-lar/. Acesso em: 13 fev. 2019.

MAKOWIECKY, Sandra. Representação: a palavra, a ideia, a coisa. Caderno de Pesquisas Interdisciplinar em Ciências Humanas, v. 4, n. 57, 2003.

MOURA, João Carlos da Cunha. Joguem como homens!: masculinidades, liberdade de expressão e homofobia em estádios de futebol no estado do Maranhão. São Paulo: Paco Editorial, 2019.

NORONHA, Marcelo Pizarro. Sou mulher! Sou gremista! Representaçóes da mulher no futebol e as cristalizaçóes de gênero envolvidas nesse processo: Uma etnografia sobre torcedoras do Grêmio. ENCONTRO ESTADUAL DE HISTÒRIA, 11., 2012, Rio Grande. Anais... Porto Alegre: Anpuh-RS, 2012. p. 640-649.

RIBEIRO, Djamila. O que é lugar de fala? Belo Horizonte: Letramento, 2017.

RIZZO, Marcel. Fifa cria projeto contra homofobia no futebol. Folha de São Paulo, São Paulo, 31 jan. 2014. Disponível em: https://www1.folha.uol.com.br/esporte/folhanacopa/2014/01/1405125fifa-cria-projeto-contra-a-homofobia-no-futebol.shtml. Acesso em: 17 dez. 2019.

SOIHET, Rachel. A pedagogia da conquista do espaço público pelas mulheres e a militância feminista de Bertha Lutz. Revista Brasileira de Educaçāo, n. 15, p. 97-117, 2000.

TOLEDO, Luiz Henrique de. Torcer: metafísica do homem comum. Revista de História, São Paulo, n. 163, p. 175-189, 2010.

\section{Fontes orais}

ARAÚJO, Daniela [28 anos]. [dez. 2019). Entrevistadora: Nathália Pessanha. Niterói, RJ, 5 dez. 2019.

CHAVES, Poliana [20 anos]. [maio 2019]. Entrevistadora: Nathália Pessanha. Rio de Janeiro, RJ, 15 maio 2019.

GOMES, Ana Luiza [21 anos]. [jan. 2019]. Entrevistadora: Nathália Pessanha. Niterói, RJ, 20 jan. 2019.

MUNIZ, Flávia [25 anos]. [out. 2019]. Entrevistadora: Nathália Pessanha. Itaboraí, RJ, 13 out. 2019.

Recebido em 22/04/2021.

Aprovado em 11/07/2021.

Fonte de financiamento: nada a declarar.

Conflitos de interesse: nada a declarar. 